\title{
Second International Small-Angle X-ray Scattering Conference
}

The Second International Conference on Small-Angle X-ray Scattering was held at the Institut für Physikalische Chemie, University of Graz, Graz, Austria, from 26 to 29 August 1970. Chairman of the meeting was Professor O. Kratky, Graz, and the Cochairman was Professor H. Brumberger, Syracuse, New York, U.S.A. Other members of the conference committee were: G. W. Brady, Murray Hill, New Jersey, U.S.A.; R. W. Hendricks, Oak Ridge, Tennessee, U.S.A.; R. Kriste, Mainz, Germany (BRD); K. Krajnc, Zagreb, Yugosla- via; W. Ruland, Brussels, Belgium; G. G. Shipley, Welwyn, Herts. England; and P. W. Schmidt, Columbia, Missouri, U.S.A.

The meeting was sponsored by the International Union of Crystallography and the Deutsche Biologische Gesellschaft. Representing the hosts were Dr Hertha Firnberg, Austrian Federal Minister for Science and Research; Dr h.c. Josef Krainer, Governor of Styria, Dipl-Ing. Gustav Scherbaum, Mayor of Graz; and Professor Karl Lechner, President of the University of Graz.
Following are the abstracts of the 64 papers actually presented. The author index is on p. 426. Some post-conference editing has been done by the Chairman in order to assure that each abstract fairly represents the author's position after his paper had been presented and had been discussed by the participants.

Where a paper has been presented by more than one author, the lecturer is denoted by an asterisk.

A critical review of the meeting, by A. Guinier and $H$. Brumberger, appears on pages 405-407.

\section{Opening lecture}

1. Small-angle scattering in crystals. By A. Gurnine, Service de Physique des Solides, Faculté des Sciences, Université de Paris, Orsay, France

A crystal perturbed by inhomogeneities gives rise to a diffuse scattering, eventually in particular in the domain of small angles. This SAS may be treated either by the general theory in some cases or must be considered merely as part of the general scattering. Examples are given chosen in pre-precipated alloys, doped ionic crystals, radiation damaged crystals and imperfectly crystallized substances as cellulose or carbon.

\section{Theory of small-angle scat- tering}

2. Interpartikuläre Interferenzen in dichtgepackten Systemen. Von G. PoROD, Physikalisches Institut, Universität Graz, Österreich

Wie P. Debye [Physik. Z. (1927). 28, 135] zeigen konnte, führt bei einem Kugelgas bereits die Undurchdringlichkeit allein' $z u$ einem Interferenzeffekt von der Art eines Flüssigkeitsdiagramms. Auch abgeänderte Stati-

\section{Abstracts}

stiken [A. Guinier \& G. Fournet, Small-Angle Scattering of $X$-rays. New York: John Wiley (1955); G. Porod, Kolloid.-Z. (1951). 124, 83; (1952). 125,51] ergeben im wesentlichen ähnliche Ergebnisse. Experimentell findet man aber in der SAXS dichtgepackter Systeme den Typ der Partikelstreuung mit besonders steilem Anstieg gegen den Winkel 0.

Die Diskrepanz erklärt sich dadurch, dass die Nahordnung der Teilchen besonders empfindlich gegen Feinheiten der Form ist. Kugeln führen immer zum liquid-type, eben begrenzte Körper wie etwa Würfel können auch das entgegengesetzte Verhalten zeigen. Mathematisch lässt sich die Streuung des Systems zerlegen [G. Porod, Int. Conf. El. magn. Scattering, Amherst (1955)] in eine Partikelstreuung und einen Anteil, der durch den Formfaktor der gemittelten Umgebung, nämlich die Abweichung von der mittleren Elektronendichte beschrieben wird. Dieser Formfaktor muss grundsätzlich eine steilere Winkelabhängigkeit haben als der Formfaktor der Teilchen. Das Vorzeichen kann positiv oder negativ sein. Das führt zu zwei qualitativ verschiedenen Streudiagrammen, mit positiver Wechselwirkung (cluster type) und mit negativer Wechselwirkung (liquid type). Diese beiden Fälle können durch stochastische Modellsysteme demonstriert werden.

In der Natur wird offenbar der cluster type häufiger realisiert. Er darf nicht mit der Partikelstreuung der Cluster verwechselt werden, wie an Hand der Modellsysteme gezeigt werden kann.

3. Theory and application of an analytical method for the evaluation of polydisperse particle systems. By $M$. TeICHGRÄBER* \& E. WALENTA, Institut für Faserforschung, Abt. Physik, Deutsche Akademie der Wissenschaften zu Berlin, Teltow-Seehof, Germany $(D D R)$

As a preliminary step, a relationship is derived for the trigonometric Fourier coefficients, $b_{n}$, of a special correlation function

$$
\begin{array}{r}
b_{n}=b_{N_{0}}+\frac{\pi}{R_{w}} \int_{u_{n}}^{u N_{0}} t . I(t) \mathrm{d} t, \\
n=1,2, \ldots N_{0} .
\end{array}
$$

$I(u)$ is the experimental scattering curve with $u=2 \sin \theta / \lambda, u_{n}=n / 2 R_{w}$ and $R_{w}$ is the 'radius of the interaction zone' [R. Hosemann, Kolloid.-Z. (1950). 117, 13].

The correlation function introduced implicitly by equation (1) is immediately related to the convolution square of the electron density in the particle system. For diluted particle 